\title{
Medical professionals and human rights in The Philippines
}

\author{
June Pagaduan-Lopez University of The Philippines, Manila, The Philippines
}

\section{Health and human rights}

For most Filipinos access to primary health care is a luxury. Often those in greatest need subsist in desperate poverty where living conditions foster illness and disease. Well over half the population live in rural areas without safe drinking water where communicable diseases, which are preventable and curable, account for 43 per cent of total deaths. The Philippines has the highest incidence of tuberculosis schistosomiasis, and polio in the Western Pacific.

Sadly enough, Filipino children suffer and die from pneumonia, nutritional deficiencies, gastroenteritis and colitis at such a rate that they make up nearly 25 per cent of total deaths in the country. Beneath the surface of these statistics lies the insidious role of poverty: malnutrition, for example, often aggravates measles, leaving affected infants susceptible to such complications as pneumonia and various forms of diarrhoea.

\section{Health care delivery}

Chronic underdevelopment in The Philippines explains much of this country's poor health record. Almost 75 per cent of Filipinos live below the poverty threshold, defined by Manila's Centre for Research and Communication as the equivalent of US $\$ 1,000$ a year for a family of six. In 1985 alone, over three million people, or 15 per cent of the total labour force of 20.6 million, were out of work. Six years later, under the Aquino government, the figure has increased to 20.2 per cent according to the July 21991 issue of $A n g$ Malaya, a Manila daily. That same year, the average employed labourer earned no more than US $\$ 60$ per month.

This grim picture is compounded by inadequate transportation and communications systems which hamper the ability of rural residents to reach health facilities in central towns and cities. Even in urban centres the high cost of prolonged institutional medical care is far beyond the means of the average wageearner. Hospitals often have to get by with inadequate supplies of $\mathrm{x}$-ray film, bed linens and antibiotics. In 1983, for instance, doctors at the Philippine General Hospital, the country's biggest tertiary state hospital, reported that a shortage of $x$-ray film had forced them to forego taking essential radiographs of many patients. Over 50 per cent of the country's doctors and more than 60 per cent of its nurses work outside of the country. Of those doctors who remain in the country, most have private practices in urban areas. Manila, the country's capital, has 15 times as many doctors as outlying rural areas.

These conditions, however, tell only part of the story. During the Marcos years, the health situation in The Philippines failed to improve because of govenmental neglect, widespread corruption and graft, plus intimidation of rural health care providers. Even though the Marcos government maintained a blueprint for primary health care facilities, its health care delivery programme was severely underfunded. In 1983, Dr Mita Pardo de Tavera, now Minister of Social Services and Development, estimated that, 'in terms of US dollar value, for every nine dollars spent per capita on military expenditures, only one dollar was spent on health care'. As a result, the number of hospital beds per 10,000 population dropped from 18 to 13 between 1977 and 1983. In 1985, the last year of the Marcos regime, the government's medicare programme was only able to cover 20 per cent of hospitalisation costs, compared to 70 per cent when the programme was first initiated in 1969.

Equally disturbing was the fact that government medicines and supplies often failed to reach hospitals and clinics because of graft and corruption. For instance, the Philippine Commission on Audit, a government agency, reported in 1984 that the former first lady's heart center had 'various anomalies' including 'the failure of management to reconcile the physical inventory of supplies, material, property and equipment with accounting records; property and equipment amounting to 300.7 million pesos remained unrecorded in the center's records'.

But such fiscal anomalies were not limited to hospitals in the metropolitan Manila area. In 1986, President Aquino's newly appointed Minister of Health, Dr Alfredo Bengzon, found that in the two years before the fall of the Marcos regime between 30 and 40 per cent of the national health budget for supplies and materials had been diverted into 'kickbacks, corruption, and graft'. As a result, Minister Bengzon dismissed eight of the twelve district 
health officers originally appointed by Marcos's health minister.

Today, in its fifth year, the Aquino government seems nowhere close to solving the myriad problems it inherited from the Marcos regime. Saddled with a deteriorating economy, destabilisation efforts from both right and left wing factions, graft and corruption and poor central planning, it has often been accused of resorting to increased militarisation to contain political violence against its continued existence.

At the time of writing, in spite of a state of emergency declaration that has been in effect for more than six months, the economy continues to deteriorate and human rights abuses to rise. The Presidential Commission on Human Rights (PCHR) reported that it received a total of 1,653 complaints in $1988,1,570$ in 1989 and 1,880 in 1990. The Catholic-Church-based Task Force Detainees of The Philippines (TFDP), has noted a higher occurrence of political arrest in the past five months - involving 305 persons, of which 70 remain in detention - than at any time since the Aquino government came into office. At the height of the Philippine-US exploratory talks in Manila in May 1990, 155 anti-US bases activists were arrested.

\section{The medical community responds}

Filipino doctors and health workers active in the human rights movement have mixed views of the role played by the Philippine medical and health associations in defending threatened colleagues during the years of martial law. The national nurses' association, they say, spoke out in defence of colleagues who were harassed or jailed for their human rights activities or non-violent opposition to the Marcos government. Similarly, some provincial medical associations, such as the Quezon Medical Society, responded with appeals and petitions when their members were detained. But, for the most part, the Philippine Medical Association (PMA) remained silent.

The PMA did, however, issue a statement in 1985 urging President Marcos to release detained doctors into the custody of the association so they could serve their patients. To protect doctors, the PMA submitted to the National Assembly a proposal providing stiffer penalties for various crimes committed by doctors against their patients. But such well-intentioned initiatives were undertaken only in the last three years of the Marcos regime. Clearly, fear of government reprisals may partly explain this lack of action. Equally apparent was the international medical community's failure to support and encourage the PMA to speak out in defence of Filipino health professionals in serious trouble. It can be argued that the often ruthless character of the Marcos government, particularly during the martial law period, afforded professional associations few possibilities for securing protection of health care providers. Even so, it is significant that the Catholic Church and members of the legal profession took public positions as early as 1975 condemning violations of human rights committed by the government.

Disheartened by the medical community's failure to formalise the creation of the Medical Action Group (MAG) and clinics for the treatment of torture survivors, a handful of doctors banded together a week after the murder of Dr Remberto 'Bobby' de la Paz, a doctor working in Catbalogan, Samar, to form MAG. Among the group's founding members were the slain doctor's wife, Sylvia, and his sister, Dr Alicia de la Paz. They soon opened a small office in downtown Manila. Now, ten years later, MAG maintains offices in several provincial capitals and performs a wide range of health care programmes, including a prison medical project, a network of primary health care programmes, $\vec{\nabla}$ educational seminars on the medical consequences of $i$ nuclear war, and clinics for the treatment of torture victims.

Since its formation, MAG has worked closely with $\stackrel{\vec{N}}{\mathrm{~N}}$ the Free Legal Assistance Group and the TFDP to gain 을 access to detainees in need of urgent medical care. In 1983, MAG reported that the following health and living conditions were common in several, if not most, of the 100 detention centres and military stockades throughout the islands: overcrowding, with common criminals and political detainees sharing the same cell; meagre food rations (roughly 6 pesos or 42 US cents day); insufficient medicine for a variety of ailment including tuberculosis, anaemia, gastroenteritis, ang colitis, and irregular visits by prison health personnel. These conditions, the group said, were further aggravated by the fact that many detainees had been held for a year under such circumstances.

During the first two years of its existence, MAG $\overrightarrow{\vec{\partial}}$ encountered several barriers to their gaining access to $\exists$ detainees who were in poor health. In 1983, for example, MAG doctors in Manila were only permitted to attend to prisoners on three occasions. In addition, the group lacked adequate resources to dispatch doctors to remote areas where detainees were often in the greatest need of medical care and basic medicines. In some areas, local military commanders were unwilling to let civilian doctors enter detention facilities to examine prisoners on the basis that such $ᄋ$ visits could only be allowed after authorisation by the prison medical system or the International Committee of the Red Cross.

Despite these obstacles, by 1984 MAG had reached agreements with several regional government and $N$ military officials, which allowed civilian doctors access $\underset{\omega}{N}$ to prisons. This new development meant that $\sigma$ detainees, particularly in areas where official prison 0 health care was non-existent, could finally receive $\frac{}{\Phi}$ urgently needed medical attention. Though certainly $\stackrel{\infty}{+}$ beneficial for detainees, the fact that civilian doctors were examining detainees in prison also meant that health professionals were in a better position to expose $\stackrel{\odot}{\overparen{D}}$ physical and mental abuse. Clearly, to some military $\mathbb{Q}$ officials, such a situation was threatening. At the same $\sigma$ time, doctors who ministered to political prisoners and 
called attention to abuse often left themselves open to reprisals for doing so.

\section{Medical participation in torture}

In nations where state-sanctioned torture becomes routine, it develops into a malignancy of the body politic, prompted and sustained by the actions of people in many sectors of society. Sadly enough, health professionals may be co-opted into the practice of torture techniques which leave few physical signs, or to monitor a victim's heart and respiratory activity so he or she does not die unexpectedly.

Professional complicity in torture has been well documented in such countries as Chile and Uruguay. In the case of The Philippines, however, there is little direct evidence that military and police medical personnel systematically transgressed their ethical responsibilities by participating in torture. Even so, Philippine human rights groups now possess several testimonials in which former detainees allege that prison medical personnel often treated them with indifference or outright hostility.

In one case, a psychology student in northern Luzon reported that after his arrest in 1983 a Philippine Constabulary intelligence officer repeatedly punched him in the stomach and neck, and at one point banged his head against the wall. The beatings stopped, he says, when his mother arrived at the detention centre. Three days later, a prison doctor examined him and signed a medical certificate stating that he bore no signs of ill-treatment even though he had signs of bruising on his stomach and head and had told the doctor of his treatment at the hands of the intelligence officer. After his release, the detainee filed a court complaint against the officer, but it was dismissed on the basis of the medical certificate.

In another case, Vicente Ladlad, who was detained in 1983 and held in solitary confinement for two years and nine months, states that in his first week of solitary confinement guards never allowed him to sleep and threatened him with 'salvaging' (extrajudicial execution by military or paramilitary agents) for failing to co-operate with his interrogators. On the sixth day, he ran a fever and was examined by a doctor. After the examination, Ladlad says, the doctor turned to his interrogator and said: 'Kaya pa niya' ('He can still take it').

Another case was that of a couple personally handled by the author. Both were referred for serious emergency psychiatric conditions only several days after their arrest. The wife had attempted to commit suicide by slashing her wrist while the husband had developed an acute psychotic reaction. In spite of a written request from the relatives and legal documents showing that the author had military clearance to examine the patients, she was denied access to these two victims. Upon release in 1986, both reported having been seen by the military camp medical officer. They were prescribed tranquillisers but were never referred for a psychiatric evaluation.
A well publicised case of torture under the Aquino government is that of Randolf Corteza. Corteza was a nurse and a part-time medical representative at the time of his arrest. Swift legal action forced the military to produce Corteza and allow him to be examined by civilian doctors. Corteza was found by a medicolegal officer of the National Bureau of Investigation and a MAG doctor to be heavily bruised and burned over his genital areas, only two days after the issuing of a medical clearance by a military medical officer.

Whether such incidents were isolated cases or part of a pattern of professional misconduct remains unclear as neither the PMA nor the PCHR have formally investigated the role of medical personnel in the treatment of detainees. It would seem timely, in the post-Marcos period, to review the status of health personnel. What for example, are the lines of responsibility for military and prison doctors in The Philippines? Do they report directly to non-medical superiors? And if so, are they required to share with them a patient's medical file without his or her prior approval? What procedures exist for prison or military doctors who wish to lodge complaints about torture or ill-treatment of detainees?

\section{The forensic sciences and human rights investigations}

Forensic science is defined as the application of science to the judicial system. It is a field of science that encompasses a wide range of scientific disciplines directed toward the resolution of legal and social controversies through the application of scientific principles and methods of analysis. Since the turn of the century, the forensic sciences have grown into an amalgamation of several different scientific disciplines - anthropology, archaeology, pathology, toxicology, chemistry, radiology, and odontology - with the goal of medicolegal examination of evidence and the presentation of these results and their interpretations to courts of law.

As with other scientific endeavours, forensic scientists are expected to be technically competent in their area of expertise; to treat all problems with equal thoroughness; to maintain complete objectivity and remain non-partisan in their examinations of evidence; and to write reports and deliver testimony in a manner understandable to non-scientists.

Clearly, forensic scientists can play an important role in investigations of violations of human rights. Through the scientific examination and analysis of lesions, forensic pathologists can detect physical signs of torture, their age, severity, and causal factor. In addition, they can perform autopsies on persons killed under suspicious circumstances to determine the cause and, in some cases, the manner of death. By combining their specialised knowledge and skills, forensic anthropologists, odontologists, radiologists, and pathologists can exhume, identify, and establish the cause of death of the skeletal remains of persons alleged 
to have been killed in official custody and later buried in a single or mass grave.

It is not surprising, however that forensic scientists have rarely been involved in human rights investigations. Central to the practice of the forensic scientists is the concept of legitimate authority. For without a legitimating authority that applies the law in accordance with international norms, the very concept of the forensic sciences is undermined. As a result, forensic scientists living under repressive regimes face several obstacles in the application of their professional skill and expertise to the resolution of possible human rights violations. In countries where abuses are widespread, forensic scientists are likely to be at serious personal and professional risk if they produce explicit evidence at variance with official explanations or which implicate govenment agents in the case under investigation. Finally, because forensic scientists work closely with official investigative agencies, they may be easily co-opted into covering up crimes committed by state authorities.

Because of these limitations, few large-scale medicolegal investigations of human rights abuses have taken place in countries with repressive regimes. Nonetheless, in recent years the newly elected governments of Argentina and The Philippines have begun to investigate the atrocities of their military predecessors. And in doing so, they have called on the international forensic science community to assist them in the collection and analysis of medicolegal evidence. One of the most important aspects of these investigations has been the training of Argentine and Filipino scientists in the specialised skills required to examine physical evidence which, over time, may have been tampered with or left unrecovered.

\section{The medicolegal system in The Philippines}

The medicolegal system in The Philippines, as in other underdeveloped countries, is not as advanced as systems in countries with greater resources. In the United States, for instance, there has been a tripling of forensic science resources since 1967 to stem an upsurge in violent crime and drug abuse. As a result, there are now over 300 forensic science laboratories throughout the country, as well as hundreds of coroner and medical examiner offices at the state, county, and municipal levels which investigate unattended, suspicious, and violent deaths.

Today there are three official investigative bodies in The Philippines - the Philippine Constabulary, the Western Police District (formerly the Manila Police Department), and the National Bureau of Investigation (similar, in many respects, to the Federal Bureau of Investigation) - which maintain medicolegal branches. The first medicolegal system was established in The Philippines in 1937 and placed under the authority of the Ministry of Justice. Two years later, the Philippine government abolished the Department of Legal Medicine at the University of The Philippines
College of Medicine and transferred its functions to the Ministry of Justice. In 1942, the City of Manila established its own medicolegal branch under the direction of the Police Department. During the Japanese occupation, however, all of the law enforcement agencies were consolidated under a single agency called the Bureau of Investigation. In 1947, two years after the expulsion of the Japanese and a year after The Philippines gained full independence, President Manuel Roxas renamed the bureau the National Bureau of Investigation (NBI) and placed a medicolegal division under its authority. Since then, most medicolegal investigations in The Philippines have been carried out under the NBI's direction.

Unlike the medical examiner or coroner system found in the US and other countries, The Philippines follows the medicolegal officer system. While the medical examiner or coroner goes to the scene of the crime, examines the body there, and later conducts an autopsy at the morgue, the medicolegal officer rarely, 을 if ever, travels to the crime scene and only sees the body for the first time on the autopsy table. Under the Philippine system, local officials are authorised to appoint doctors from hospitals, clinics, asylums, and prisons as ex-officio medicolegal officers. As of December 1986, there were medicolegal officers in eleven regional offices throughout the countro However, because of a shortage of doctors on the island. of Mindanao, most of the medicolegal cases on the island are sent to the Cebu City office nearly 250 miles away on the island of Cebu.

The medicolegal officer system, as many Filipino doctors and pathologists concede, often means that autopsies in criminal cases are performed by medical practitioners who possess limited or no knowledge of forensic pathology. According to $\mathrm{Dr}$ Ricardo $\mathrm{G}$ Ibarrola, NBI Assistant Chief Medicolegal Officer in Manila, 'Some members of the medical profession have been inclined to regard medicolegal matters with $\overparen{\Phi}$ abhorrence. They consider them as an addition to their usual duties while others refuse to handle medicolegal cases because of fear or because of the waste of time involved when they are summoned by the courts'. Moreover, since most of the regional medicolegal 을 offices have no morgues of their own, autopsies are $>$ often conducted in funeral homes or even in the homes of victims.

Unless a complaint is filed by the relatives of the victim or other concerned persons or groups, an investigation to determine the perpetrator of the crime $\underset{\omega}{N}$ is usually not conducted. If it is determined that there were no witnesses to the crime or the witnesses cannot 0 be persuaded to testify, which is the usual case in $\frac{}{\Phi}$ instances of 'salvaging' and torture, or if it cannot be $\stackrel{\mathcal{P}}{+}$ determined how the crime was committed, secondary evidence, such as photos can be submitted as evidence.

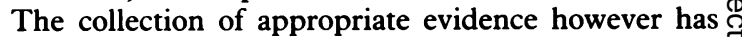
proved difficult for lawyers who have attempted to $\stackrel{\mathbb{Q}}{\Omega}$ prosecute such cases. Expert witnesses, usually $\overline{0}$ doctors, are called upon to give their opinions. But 
human rights lawyers have experienced cases where two contrary expert witnesses' testimonies have been presented and the judge has had to decide which testimony is to be accepted by the court. Even with the submission of autopsy reports and medical findings, if there are no witnesses, the courts may dismiss the case because they believe there is no one to prosecute or establish a case against.

During the Marcos years, these conditions, as well as the lack of independence of the judiciary, meant that few cases of human rights violations particularly those involving torture and 'salvagings', were ever investigated. An unprecedented series of investigations did take place, however, following the 1983 assassination of Benigno Aquino Jr. Clearly, the national and international stature of the late senator, coupled with questions of the possible high-level government involvement in the planning and execution of the crime, made the Aquino case exceptional. Even so, the events surrounding his murder and the irregularities in the subsequent investigation illustrate how easily the forensic sciences can be manipulated as well as the extent to which the rule of law in The Philippines had been eroded under the authoritarian government of Ferdinand Marcos.

\section{Presidential Commission on Human Rights}

The medicolegal investigation of Benigno Aquino's murder strained the capabilities of the Philippine judiciary and medical profession. But the slain senator was not alone in his fate, and Corazon Aquino is not the only human rights widow of the 1970s and 1980s. In The Philippines, there are thousands of nameless Aquinos. All of them have become the inevitable responsibility of the PCHR.

Weeks after assuming the presidency, Corazon Aquino established the commission and appointed the distinguished lawyer and former senator, Jose W Diokno, as its chairman. The commission is charged to investigate past and present governmental human rights abuse and report its findings to the president. For the most part, the PCHR has been concerned with assisting the government to formulate measures aimed at protecting human rights and with establishing a procedure for receiving human rights complaints.

In its first interim report (Resolution CHR-No 1, April 14, 1986), the seven-person commission proposed several measures to improve compliance with, or to strengthen, existing laws related to human rights. The measures included: disarming and disbanding of paramilitary groups; banning secret arrest and detentions and incommunicado detention; suspending from office those charged with human rights abuses; increasing the penalties for those convicted of human rights abuses; making certain rights absolute even under martial law; allowing inspection of all detention centres, and ratifying Protocol II of the Geneva Convention. Alas, none of these recommendations have been implemented by the Aquino government to date.

\section{UNRELEASED DETAINEES}

One of the commission's primary functions has been to review the cases of political prisoners who have remained in detention despite presidential amnesty. Human rights groups claim that instead of releasing these detainees, arresting officers have resorted to belated charges of criminal offence such as robbery and murder. Technically speaking, persons charged with criminal offences fall ouside of the president's amnesty and are therefore ineligible for immediate release.

By June 1986, the volume of criminal cases 'allegedly tainted with political colour' had reached such a level that commission members queried the Minister of Justice on the matter. The latter replied, saying that there was little he could do in such cases because a release petition could only be considered 'after the trial fiscal and/or the offended party shall have been given an opportunity to be heard' by a criminal court. He did suggest however, that persons charged with criminal offences but who may, in fact, be held for political reasons, 'could be released through the process and application of the rules of bail'.

For these detainees the prospects of release, let alone a speedy case review, appear to remain uncertain for several reasons. First, the dockets of criminal courts are overloaded, creating a backlog of cases that may take months to resolve. Second, many detainees are impoverished subsistence farmers who are unable to pay bail costs. Finally, detainees held in the provinces often lack assistance from legal counsel except where it is offered on a volunteer basis through such groups as the Free Legal Assistance Group, which retains lawyers in some, but not all, areas of the country.

\section{ARBITRARY KILLINGS}

Despite the Aquino government's efforts to bring the armed forces under full civilian control, the PCHR has continued to receive reports of killings of civilians by military personnel and members of the New People's Army (NPA) and the Moro Islamic Liberation Front, in several areas of the country, particularly on the islands of Panay and Negros. The Provincial Human Rights Committee on the island of Panay reported in August that the increased military presence on the island since April had resulted in 13 cases of 'salvaging' and the burning of five houses by military troops. Similarly, in September, the Moro Islamic Liberation Front, a Moslem separatist group unconnected to the NPA, claimed responsibility for an attack on a Roman Catholic wedding ceremony that left 10 people dead and 96 wounded.

\section{FORCED RELOCATIONS OR 'HAMLETTING'}

Since 1983, military operations in the eastern Misamis region of Mindanao island has resulted in the forced relocation of thousands of subsistence farmers and their families. In June 1986, several human rights groups, with the endorsement of PCHR member Haydee Yorac, sent a fact-finding and medical mission 
of inquiry to the region to investigate conditions at evacuation centres and to provide medical care to displaced persons. The mission found that of the 4000 displaced families in the area the majority had been forced to evacuate their homes since January 1986. Evacuation centres, the medical team reported, were 'totally inadequate' to meet the health needs of evacuees. Most centres, they said, 'do not have a potable water supply. Houses are congested and very few have toilets. The surroundings are dirty, unfit for healthy living. Domestic animals roam around freely'.

Most alarming, according to the medical team, was the effect that health conditions have had on childen living at evacuation centres. In the 1970s, 'very few [of these] children who had succumbed to pneumonia had measles', the team noted. But in the 1980s 'many of the children who died of pneumonia had measles too'. The team also found that both the number of diagnosed cases of malnutrition and deaths as a result of malnutrition in children had increased significantly since the evacuations in the eastern Misamis region began more than three years ago.

\section{THE 'DISAPPEARED'}

So far, the only concerted effort to apply forensic science in investigations of human rights abuses has been made by the PCHR in their attempts to identify and determine the cause of death of the 'disappeared'. Most of the missing are assumed to have been killed by military or paramilitary and later buried in unmarked graves.

'Disappearances' in The Philippines took a sharp rise shortly after President Marcos suspended the writ of habeas corpus in 1972. Some prisoners became 'salvaging' victims, their mutilated bodies found by the roadside or in shallow graves, while other prisoners reappeared in military detention camps after several weeks or months of interrogation and torture in safehouses. A third category of prisoners, bnwever, 'disappeared' after detention and were never seen again by their families, despite countless appeals to Marcos officials.

Philippine human rights groups estimate there are 666 political detainees whose whereabouts and legal status were never publicly acknowledged by the Marcos government. The number of 'disappearances' rose to 131 in 1984 and peaked the following year at 174. And despite the Aquino government's efforts to stop the practice, 'disappearances' continue to be reported up to the present time. Cecilia Lagman, president of the Families of Victims of Involuntary Disappearances (FIND), says that many relatives of these 'disappeared' prisoners have accepted the possibility that their loved ones are dead. Lagman and the other 33 FIND members believe that most, if not all, of those still missing were killed after arrest and later buried in remote areas.

In an attempt to aid the families of the 'disappeared', the PCHR asked the Minister of Health in June 1986 to instruct all provincial health officers 'to inform the commission of any unidentified bodies they have examined ... and to provide (the commission) with pertinent medical certificates'. In December 1986, the PCHR and several human rights groups sponsored a two-week training course in the identification of skeletal remains. An international team led by $\mathrm{Dr}$ Clyde C Snow, an American forensic anthropologist, directed the course at the University of The Philippines College of Medicine and carried out several exhumations at a mass-grave site in Cavite.

Since 1984, Snow and a team of Argentine graduate students have been assisting the Argentine government in its efforts to locate and identify the remains of nearly 10,000 persons who were abducted and killed during military rule in the $1970 \mathrm{~s}$. Using archaeological techniques, Snow and his Argentine colleagues have exhumed and identified several of the missing and presented their findings to civilian judges. Snow, whose participation in the Argentine forensic investigations was sponsored by the American Association for the Advancement of Science (AAAS), testified in the 1985 trial of the military juntas who ruled the country between 1976 and 1983 .

Thirty-four Filipino health professionals and scientists attended the forensic training course held in Manila in late 1986. Among them were representatives from the Philippine Ministry of Health, the National Bureau of Investigation, private health groups and university medical schools. During the training course, Snow and his fellow instructors led the participants in the exhumation of two unidentified bodies, one which had been buried along the side of a remote road in the area of Cavite and the second which had been brought to a local cemetry and interred there. Five other unidentified bodies which had been exhumed in the same area in Cavite and reburied in January 1986 were re-exhumed. All of the remains were taken to the medical school laboratory where they were studied for clues as to their identity and cause of death.

In addition to the Presidential Commission on Human Rights (PCHR), the other sponsors of the training course were the Medical Action Group (MAG), the Families of Victims of Involuntary Disappearances (FIND), the Department of Pathology of the University of The Philippines College of Medicine, the Argentine Institute for Human Rights, the American Association for the Advancement of Science (AAAS), and the Committee of Concerned Forensic Scientists (CCFS).

At the close of the training course, the participants adopted a resolution calling on the PCHR to: create a subcommittee on 'disappeared' persons; authorise exhumations of graves of unidentified persons with the intention of creating a repository for the remains and a databank of all relevant information including antemortem medical records and $\mathrm{x}$-rays; provide official support for the dissemination of the knowledge and skills acquired at the workshop, and to facilitate legal proceedings against those implicated in cases of 
'disappearances' once scientific evidence had been collected.

\section{Medical education and the new constitution}

The most fundamental challenge that health professionals face in their efforts to protect human rights is to make governments recognise that professional complicity in abuse, while not only morally wrong, is also a serious breach of medical ethics. Sadly, health professionals in The Philippines and the world over receive little, if any, educational instruction about their ethical and legal obligations, so far as international human rights standards are concerned. Even so, the Aquino government's commitment to human rights suggests that medical schools in The Philippines should soon adopt a programme on medical ethics and human rights. But to ensure that this takes place, medical groups experienced in human rights matters, such as the MAG, will have to take the lead in aiding medical educators in the development of course work materials.

Much work remains to be done to develop educational materials that address specific ethical dilemmas in the area of medicine and health care delivery. President Aquino's Minister of Health, Dr Alfredo Bengzon, concedes, for example, that professional ethics courses taught in medical and nursing schools in The Philippines are poor in substance and have concentrated almost exclusively on issues of medical jurisprudence. He attributes this situation to the high migration of young doctors and nurses to developed countries where they are more likely to encounter legal liability issues in their work than in The Philippines. As a result, he says, medical educators tend to neglect the more fundamental precepts that should guide the quality and kind care doctors and health workers render to their patients daily.

The Hippocratic Oath and modern codes of ethics are testaments to the long-standing concern for standards of conduct within the medical profession. In modern times health professionals and the public alike have advocated various standards for the care of the dying and the handicapped, medical participation in the prison health care system, euthanasia, eugenics, triage, and the cost-effectiveness of medical procedures. All of these issues, in addition to the relevant human rights standards pertaining to medical ethics, could be easily integrated into a medical ethics course.

Among the international codes of ethics that could be included in such a course are: Principles of Medical Ethics Relevant to the Role of Health Personnel, Particularly Physicians, in the Protection of Prisoners and Detainees against Torture, and Other Cruel, Inhuman or Degrading Treatment or Punishment (adopted by the UN General Assembly, 1982); the Declaration of Tokyo (adopted by the World Medical Association, 1975); Regulations in Time of Armed
Conflict (adopted by the World Medical Association, 1956, 1957, 1983); the Resolution of Singapore: Role of the Nurse in Care of Detainees and Prisoners (adopted by the International Council of Nurses, 1975), and the Statement on the Nurses' Role in Safeguarding Human Rights (adopted by the International Council of Nurses, 1983).

Furthermore, medical and nursing colleges should consider adopting the 1978 UNESCO guidelines for the teaching of human rights. The guidelines recommend, for example, that professional school training emphasise the lessons implicit in case studies drawn from indigenous human rights issues and cases. Several of the cases of doctors mentioned in this report could serve as examples.

President Aquino has already laid the framework for introducing human rights education as an integral part of the nation's educational system. In July 1986, she issued presidential memorandum No 27 , requiring the teaching of human rights at all levels of education. In an adjoining memorandum, she stated that the study of human rights would become 'an integrated and indispensable part' of military and police training. The memorandum specified that the continuance in office of all police and military enforcement personnel 'shall depend on their successsfully completing the courses offered' under the human rights educatio programme.

The constitutional commission charged with writing a new plan of government also took human rights education seriously. The draft, adopted by a vote of 442, followed the president's lead by stating that: 'The state shall enforce the teaching of human rights at all levels of education, as well as in non-formal training to persons and institutions tasked to enforce and guarantee the observance and protection of human rights'.

The new constitution's bill of rights contains strong protective provisions against authoritarian rule and abuses of personal security. One provision strictly prohibits the practice of arbritary arrests in the absence of a lawful order of a court or as provided by law, and the use of safehouses or unofficial detention centres. Another stipulates that: 'No torture, force, violence, threat, intimidation or any other means which violates the free will shall be used ...' against any person under criminal investigation. The charter also bans the use of 'physical, psychological or degrading punishment against any prisoner or detainee or the use of substandard or inadequate penal facilities under subhuman conditions'. It instructs the national legislature to provide penal and civil sanctions for human rights offences, as well as 'compensation and rehabilitation of victims of torture or similar practices, and of their families ...'. The bill of rights also abolishes the death penalty and provides sentences of life imprisonment for prisoners already facing the death sentence (numbering about 650).

One section of the constitution is devoted to issues of $\bar{q}$ social justice, 'to enhance the inalienable right to 
dignity'. Other provisions deal with land distribution and labour policy, agrarian and natural resource reforms, the problems of the urban poor and housing, education, women, indigenous people, and 'the people's right to health'. Health care is to be promoted through a comprehensive programme that 'shall make essential goods and social services available to all citizens at affordable cost, with priority for the need of the disadvantaged, sick, women and children, aged and disabled'.

Among the beneficiaries of the new constitution are groups that monitor civil rights. In addition to guarantees of freedom of expression and association, the constitution provides safeguards for the 'right to information on matters of public concern', including access to 'government research data used as a basis for the policy development ...'. In an apparent recognition of the February Revolution, the constitution states: 'In the pursuit of the ends of social justice, the state shall respect the independence and the role of people's organisations as a principal means of empowering the people to pursue and protect through peaceful means their legitimate and collective interests and aspirations'.

Throughout the process of drafting the new constitution, commission members sought outside views regarding certain provisions. For example, Commissioner Minda Luz Quesada enlisted the participation of several health task forces to provide her with a series of 'concept papers' on health policy. Published by the Health Action Information Networks (HAIN), the papers examined a wide range of health issues including public health education at the grassroots level, the cost-effectiveness of existing health services, and the exploitation of health care consumers by national and foreign drug companies. According to Commissioner Quesada, HAIN's 'participation in research' efforts directly influenced the content of the social justice provisions of the constitution.

\section{Conclusions and recommendations}

\section{THE RIGHT TO HEALTH}

Article XIII, 1, of The Philippines Constitution of 1987 provides that 'the state shall adopt an integrated and comprehensive approach to health and other social services available to all people at affordable cost. There shall be priority for the needs of the underprivileged, sick, elderly, disabled, women and children. The state shall endeavour to provide free medical care to paupers'. In effect, this article maintains that the right to health is a state responsibility.

What remains to be seen, however, is the extent to which The Philippines medical community and the new National Assembly will act to fulfill this responsibility by closing the gap between available medical knowledge and services on the one hand and their application and delivery on the other. To this end, we wish to underscore several general precepts and to make specific recommendations which we believe should be taken into account in the national effort to bring health care to all those in need.

1. We suggest that new incentives be developed to ensure that doctors, nurses, and paramedical personnel respond to the health needs of underserved populations, especially the rural and urban poor and tribal peoples. The aim should be to direct both health personnel and services to geographic areas in greatest need. Such incentives could include: pay benefits for health personnel who choose to minister to underserved populations; requirements at the university and vocational level aimed at sending students in the medical and health sciences to work in areas where health services are unavailable, and scholarship programmes that would encourage Filipinos in underserviced areas to receive training in basic health skills. Furthermore, high priority should be given to developing public policy and educational efforts to stem the high migration of Filipino health professionals to other countries.

2. Since planning for the health needs of The Philippines requires reliable information, adequate resources should be provided and methods developed for the collection of accurate epidemiological data and information on health conditions throughout the country. In addition, non-governmental health groups should be encouraged to evaluate official health dat and to make their findings known to the general public.

3. Government health programmes should be developed to educate Filipinos about the basic procedures for identifying certain diseases so that patients can be referred to clinics and hospitals. Church-based and other private community health programmes have made significant advances in educating the rural and urban poor on such matters, but their resources are limited. The national media could play an important role in educating the public about health hygiene. University journalism departments, for instance, could develop writing programmes in conjunction with public health departments to train both health professionals and journalists in the most effective means of communicating basic health information to the general public. Television and radio could devote more air time to the coverage of health matters and the presentation of educational programmes on health care.

\section{THE PROTECTION OF HEALTH PROFESSIONALS}

During the Marcos years, many Filipino doctors and health workers were fearful of speaking out against human rights abuses. Public criticism of the government, particularly during the martial law years, often resulted in the loss of a promotion, a job, or imprisonment. To be sure, some health professionals profited from the government's emphasis on urbanbased tertiary-care facilities and chose to remain 
'apolitical'. Others openly criticised the government's failure to develop primary health care programmes or protested violations of human rights and, in some cases, suffered reprisals for doing so.

Several provisions of the new constitution provide for the protection and promotion of human rights. The bill of rights states: 'No person shall be deprived of life, liberty, or property without due process of law, nor shall any person be denied the equal protection of the laws'. The charter also provides for the creation of 'an independent office called the Commission on Human Rights' to replace the PCHR. The commission is empowered to 'investigate, on its own or on complaint by any party, all forms of human rights violations involving civil and political rights'. Similarly, it will 'exercise visitatorial powers over jails, prisons, or detention facilities'.

\section{THE ETHICAL AND SOCIAL RESPONSIBILITIES OF HEALTH PROFESSIONALS}

Filipino health professionals and private health groups concerned with human rights deserve special credit for their public service. The MAG and its project for rendering medical care to torture victims, the Philippine Action Concerning Torture (PACT), has begun to enunciate the elements of a new serviceoriented philosophy for health care providers. But the momentum gained by MAG and other groups will need to be sustained through collaborative efforts with university medical and nursing faculties, professional associations and government health agencies. We believe there are several steps that could be taken to further the training of health professionals in their professional duties and responsibilities.

1. Professional ethics curricula for health care providers should be developed to incorporate international standards for human rights. The 1978 UNESCO guidelines for human rights teaching provide several suggestions for inclusion of human rights norms in university and vocational school training, including the use of indigenous case studies. Curricula could include, for example, the examination of such issues as child abuse and torture, practices generally hidden by their perpetrators. Course work could begin with class discussions about the nature of these abuses. How are they similar or different? And what are the moral, ethical, and legal responsibilities of health care providers in bringing these abuses to the attention of the medical community and the authorities? Several other human rights and ethical issues could be discussed, including questions concerning doctor/patient-prisoner confidentiality as well as human experimentation in prisons.

2. Developing curricula on human rights and ethical matters and providing treatment to victims of human rights abuses need not be costly undertakings, though they will likely require support from national and international foundations. We believe foundations concerned with health and human rights should continue to provide funds to projects such as PACT. While the human rights situation has improved substantially in The Philippines, there remains a need to change the infrastructures that permit violations of human rights to take place. And, as is often the case, those groups with the will and expertise to initiate change lack sufficient financial support to do so.

It is difficult to be sanguine about stopping egregious violations of human rights worldwide. But, as the Filipino people demonstrated in February 1986, the mobilisation of public opinion and pressure can be effective in ending a heinous past. And, as Filipino health professionals have shown, individual and collective action on the part of concerned professionals can make a significant contribution to upholding personal freedoms and social justice. The February Revolution was a historical landmark in non-violence which brought new hope to the Filipino people and to all those concerned with protecting and promoting international human rights. Similarly, the Philippine Constitution of 1987 contains some of the most progressive safeguards for human rights of any charter in force in the world today. These initiatives have placed The Philippines on an exemplar path which, in the field of human rights, could be one of world leadership.

\section{Acknowledgement}

This paper is largely based on a book I co-authored with Professor Richard Claude and Eric Stover, Health Professionals and Human Rights in The Philippines, which was published by the AAAS, Washington DC, 1987.

Dr Fune Pagaduan-Lopez, $M D$, is a Psychiatrist in the Department of Psychiatry, the University of The Philippines, Philippine General Hospital Medical Centre, Taft Avenue, Manila, The Philippines. 